${ }^{3}$ Bluglass R. The psychiatric assessment of homicide. Brf Hosp Med 1979; $22: 366-77$.

${ }^{4}$ Bunker HA. Mother-murder in myth and legend: psychoanalytic note. Psychoanal $Q$ 1944;13:198-207.

${ }^{5}$ Lindner R. The equivalents of matricide. Psychoanal $Q$ 1948;17:453-70.

${ }^{6}$ Rubinstein LH. The theme of Electra and Orestes: a contribution to the psychopathology of matricide. $\mathrm{Br} \mathcal{F}$ Med Psychol 1969;42:99-108.

${ }^{2}$ Wertham F. Matricidal impulse: critique of Freud's interpretation of Hamlet. Fournal of Criminal Psychopathology 1941 ;2:455-64.

${ }^{8}$ Wertham F. The catathymic crisis. In: Kutash IL, Kutash SB, Schlesinger LB, eds. Violence-perspectives on murder and aggression. San Francisco: Jossey-Bass Inc, 1978.

${ }^{8}$ McKnight CK, Mohr JW, Quinsey RE, Erochko J. Matricide and mental illness. Canadian Psychiatric Association fournal 1966;11:99-106.

${ }^{10}$ Royal Medico-Psychological Association. Matricide. Lancet 1963 ;i:1083-4.

11 Gillies H. Murder in the west of Scotland. Br f Psychiatry 1965;111 1087-94.

${ }^{12}$ Schwade ED, Geiger SG. Matricide with electroencephalographic evidence of thalamic or hypothalamic disorder. Diseases of the Nervous System $1953 ; 14: 18-20$.

${ }^{13}$ Winfield DL, Ozturk O. Electroencephalographic findings in matricide. Diseases of the Nervous System 1959;20:176-8.

${ }^{14}$ Hill D, Sargant WA. A case of matricide. Lancet 1943;i:526-7.

15 Green CM. Matricide by sons. Med Sci Law 1981 ;21:207-14.

${ }^{16}$ Böker W, Häfner H. Gewalttaten Geistesgestörter-eine psychiatrischepidemiologische Untersuchung in der Bundesrepublik Deutschland. Berlin: Springer-Verlag, 1973.

17 Guze SB. Criminality and psychiatric disorders. Oxford: Oxford University Press, 1976

${ }^{18}$ Duncan JW, Duncan GM. Murder in the family. In: Kutash IL, Kutash SB, Schlesinger LB, eds. Violence-perspectives on murder and aggression. San Francisco: Jossey-Bass Inc, 1978.

\section{Time for a change of MIND?}

The National Association for Mental Health was formed in 1946 by the amalgamation of the Central Association for Mental Welfare, the Child Guidance Council, and the National Council for Mental Hygiene. In 1970 the association was renamed "MIND"- a change of title that seemed to follow a gradual shift in the political attitudes of the National Association for Mental Health to a more active stance over the previous 10 years, during which many proper criticisms of the mental health services had become sharp, confident, and, most important, public.

Now MIND is the leading mental health organisation in England and Wales; it offers a comprehensive range of information, educational, and therapeutic services and campaigning activities to the mentally disabled and to their relatives and professional helpers. The national operations are co-ordinated from a prestigious London head office and five regional resource centres. Much good mental health work is done by the voluntary members of the 160 affiliated local MIND associations.

Yet, while few would deny MIND's impressive successes as a pressure group in the general interest of psychiatric patients, many do regret that its continued, often inappropriate use of aggressive, confrontational, and uncompromising civil libertarian tactics has progressively lost the organisation medical sympathy. Nevertheless, some signs have recently emerged $^{1}$ of a change for the better in the role of MIND in relation to psychiatry; not the least among them is a belated recognition that MIND cannot function to best effect without active co-operation from the medical profession.

Further indications of such improvements came during the 1981 MIND annual conference "Psychiatric Treatment-Art or Science ?," held in London last month. That a rapprochement is overdue may be judged from the fact that of the 600 delegates to the conference only a dozen were psychiatrists.
In contrast, and significantly, psychiatric academics predominated among the speakers at the plenary sessions. Indeed, the proceedings were influenced by two interdependent issues of special interest to doctors: the nature and efficacy of psychiatric treatments, and the prospects for the delivery of comprehensive mental health care in an economic season characterised by a drought of financial resources and a deluge of need. The consensus was that psychiatric treatment comprises a variety of physical, psychological, and social measures and that each prescription is guided partly by intuition and partly by reference to a body of systematic knowledge such as psychopharmacology. Many non-medical participants still seemed to place naive faith in the effectiveness of some treatments, especially "dynamic" psychotherapy, in the management of chronic psychiatric conditions and even in the prevention of mental disorders. A more realistic view prevailed among the majority, but clearly all mental health professionals need to develop more informed and critical attitudes about their treatment interventions.

The conference was also concerned with other, more mundane problems. Even now certain psychiatric patient groups (the elderly, the chronically mentally ill, and patients in special hospitals) tend to receive poor care, and their future expectations are little better. The prospects are equally bleak for the greater number of patients with minor psychiatric ailments who are treated in general practice. Meanwhile, just $4 \%$ of British medical graduates enter psychiatry, and half of all psychiatric trainees come from overseas. Where will the solutions come from to these problems? Perhaps NHS psychiatrists-who should give a lead-and their professional colleagues might do better in attracting skill and funds for psychiatric services and research if they began to organise their efforts in a way which might convince sceptical onlookers that psychiatry can be efficient; that current treatments are of general application and benefit to the bulk of the population (rather than to an elite section); and that their hard work can lead to achievements comparable with those in the other medical specialties.

Senior Registrar in Psychological Medicine,

GREG WILKINSON

King's College Hospital,

London SE5 9RS

${ }^{1}$ Smythe T. The role of MIND in relation to psychiatry. Bulletin of the Royal College of Psychiatrists $1981 ; \mathbf{5}: 140-3$.

\section{Paediatricians and the law}

Paediatricians-and indeed all doctors-will have been relieved that Dr Leonard Arthur was acquitted of the criminal charges made against him after the death of a baby with Down's syndrome ( $p$ 1340). In particular, the profession will be grateful to the President of the Royal College of Physicians, Sir Douglas Black, for the clear and forthright way in which he gave his evidence. Nevertheless, relief will be tempered with anxiety: will more similar charges be brought? The LIFE campaigners have lost this round in their attack on selective treatment for handicapped neonates; but their criticisms will not have been halted.

Doctors who believe that their management of newborn babies with severe handicaps was right in the past should not be deflected by Dr Arthur's experiences. In such cases the guiding principles must continue to be the welfare of the baby in the light of the parents' decisions. The first step should, 